\title{
Quranic Features of Healing and Treatment: an Indexing of Quranic (Medical Instructions) Verses
}

\author{
Dr. Abdul Rahman Obeid Hussein \\ Dr. Adnan Mohamed Yusoff \\ Syed Ahmad Tarmizi \\ Syed Omar
}

Mohd Zohdi Mohd Amin

Lecturer at Faculty of Quranic and Sunnah Studies,

Islamic Science University of Malaysia. Bandar Baru Nilai, 71800,

NilaiNeggeri Sembilan, Malaysia

doi: 10.19044/esj.2016.v12n26p262 URL:http://dx.doi.org/10.19044/esj.2016.v12n26p262

\begin{abstract}
This paper deals with an important issue in religious thought (religion and modern sciences), which was a great challenge to the eternal validity of the text. Quran, as a revealed book, proved its power in term of legal system, and theological and philosophical presence. However, there has been a controversy on this subject. This paper used the descriptive method in presenting this topic. The researchers found that the major works on this issue have been done by Tantawi Jawhari, Maurice Bucalle, and Zaglul al-Najjar. Additionally, this context has a crucial role to play in classifying some verses as miracles of the Quran.
\end{abstract}

Keywords: Features, Healing, Context, Quranic marvels, Verses Index, Modern Sciences

\section{Introduction}

Apart from the controversy over the sanctity of the Quran, there are elements of truth or myth of revelation and the subsequent opinions about the absolute and relative: Does the Quran provide medical instructions and guidelines for physical and psychological treatment? This paper attempts to set a preliminary and simple indexing of Quranic verses that are relevant to healthcare, preventive healthcare, psychological treatment, and medicine. It is known that a range of verses mentioned in chapter of Mu'minun/Zumar, which has expounded the details of embryo and uterus, became a recorded model for researchers. However, the extreme clarity of such medical indications in the Quran is not applicable to all verses we are about to index. Consequently, at 
the same time, all verses that do not signify a medical meaning will be discarded. Any attempt in this field should start from previous indexing of the quranic verses and topics like Concordantiae of Flugel and many other works of Muslim scholars. Also, it must show the power of interpretation within the context. Thus, the classification of the topics in this indexing will be based on branches of medicine in alphabetical order, rather than on the classical method of dividing verses into meccan and medinan or according to Uthmanic codex. Based on these details, the paper will be divided into the following: Introduction to the (Quran and science); Direct and indirect indications to the medical issues; The role of context in verses indexing; and Preliminary and simple indexing of a range of selected verses.

\section{Jewish and Christian Challenges in the $19^{\text {th }}$ Century}

In the nineteenth century and after the dominance of positivist thought on political institutions, educational, and cultural aspects in the West, and after the decline of the Church's role, Jewish thinkers encountered (more harshly than their counterparts Christians) various challenges affecting their religious experience and identity. Therefore, the consequences of positivist applications were catastrophic to all religions in every sense. While western Jews had become most creative in European culture, their own Jewish culture has lost its importance to many of them (Monika Richarz, P. 84-85).

An eminent Jewish philosopher, Hermann Cohen (1842-1918), stood the strain and had a great attempt to prove that Judaism religion is kept at the level of intellectual depth as well as the function of the spiritual. He carved out his name next to other shining names in his time through his huge project: Religion of Reason, Out of the Sources of Judaism. Also, in his book, he responded to the challenges of theoretical Marxist, early Darwinism, Positivism philosophy of Kant, and the philosophy that Cohen himself was well versed and erudite in. In addition, the encyclopedic work (Church Dogmatic) of Karl Barth (1886-1968) was a reaction to the new challenges in Christianity.

\section{Quran and Science}

Writing about Quran and science raises several questions about the authenticity of the Quran, the relationship between the findings of contemporary science and holy books in general, hermeneutic, and the development of text interpretation in the last hundred years. It also include the cumulative social memory of the dominance and eternal validity of Quran, the interaction of younger generations with the scientific courses of interpretation, fervent drifting behind of a phantom series of text interpretations that put the process of exegesis on a touchstone of a dangerous experience. It shows, at the same time, the little laboratory efforts of the religious institutes. 
Commentators used to emphasize an important base before going into the relationship between scientific discoveries and the verses of the Quran. First and foremost, the Quran is a book of guidance, and not a book of philosophy, astronomy, medicine, engineering, or physics. Therefore, its language and content fits the mind of deferent cognitive levels (Al-Nejjar, 2003). Also, the data of scientific verses are mostly free of details.

Many contemporary Muslim thinkers did not show any despondency to atheist allegation that eradication of faith is out of question. Thus, the possibility to disfigure religious thought is always obtainable. Their experience with Christianity was a comfortable bet, but those contemporary thinkers' confidence in the function of Quranic scientific facts was an effective instrument towards this challenge.

Tantawi Jawhari (1870-1940) is the real founder of the art of text interpretation in the light of modern discoveries in his commentary. He was too enthusiastic and he stuffed up his commentary with pictures of plants, animals, planets, and many other empirical experiments that he quoted from Western journals and magazines. On the other hand, classical scholars were not satisfied and the Kingdom of Saudi Arabia nullified his commentary and listed it among the forbidden books. Furthermore, one of the Arab modernist described his commentary as the legendary cave of Ali Baba (AL-Sharfi. 1991). Nowadays, many are following Jawhari's steps. Also, they are repeating the same anecdotes, at the same time, about his commentary that contain everything except interpretation.

In this respect, Maurice Bucalle (1920-1998) became the most influential figure after Jawhari in his inspiring book titled "The Bible, The Quran and Science.” Subsequently, his book animated the art of Quran and science and encouraged hundreds of Muslim scholars like Abdul Majeed AlZindani, Harun Yahya, and Zaglul Al-Nejjar to work on this topic.

\section{The Role of Context in Verses Indexing}

Context has a crucial role in classifying some verses under the topic of Quran and modern science. For instance, the glorious verse (21: 30) states:

"Have not the unbelievers then beheld that the heavens and the earth were a mass all sewn up, and then we unstitched them and of water fashioned every living thing? Will they not believe?" (Arberry, 1955)

The above verse was interpreted in this way for 1400 years until anonymous scholars found that it is about the theory of big bang. However, the context is a polemic argumentation about resurrection and the Day of Judgment.

Consequently, such application, de-text of the holy book out of the context, has been used widely by Christian and Jewish theologians in their desperate attempts to capture some miracles from the prophecies of the old 
and new testament. Modern social sciences also paid attention to the systematic relationship between social and cultural context, and the structure and functions of language (Dijk, 1977, P.9). Thus, it seems these attempts have no reflection on the modern Muslim theologians who are eager to find some similarities between new discoveries and some Quranic verses.

Another example of the false miracles of the Quran could be read in some modern understanding of this verse (27: 18):

"And his hosts were mustered to Solomon, jinn, men and birds, duty disposed, till, when they came on the valley of Ants; an ant said: Ants, enter your dwelling-place, lest Solomon and his hosts crush you!"' (Arberry, 1955)

The word "crush" which is in Arabic (يحطمنكم) was given a new meaning. According to the ant, body components were revealed! Since these components were described in details only in $20^{\text {th }}$ century, the verse description is miraculous! Also, this story became very famous through the internet and social media. In recent times, linguistic reading has been used to figure out childish discoveries. Is it a miracle to know that crushing some ant is like crushing a small piece of glass?

\section{Direct and Indirect Indications of the Medical Issues}

Our last statement about "false miracles of Quran" does not mean that Quran is out of scientific signs. Therefore, the traumatic and exact model for such sign can be seen in the verse (39: 6):

"He created you from a single soul, then from it He appointed its mate; and He sent down to you of the cattle eight couples, He creates you in your mother's wombs creation after creation in threefold shadows" (Arberry,1955)

Also, verse (23: 13-14) states:

"Then we set him, a drop, in a receptacle secure; then We created of the clot a tissue; then We created of the tissue bones; then We garmented the bones in flesh; thereafter We produced him as another creature. So blessed be God, the fairest of creators!" (Arberry, 1955)

The first verse (23:14) states: "We fashioned the thing which clings into a chewed lump of flesh and We fashioned the chewed flesh into bones and We clothed the bones with intact flesh."

Here, the word "Chewed flesh" is the translation of the word "mudga", while the word "intact flesh" is the translation of the word "lahm." This distinction needs to be stressed. The embryo is initially a small mass. At a certain stage in its development, it looks to the naked eye like "chewed flesh." In addition, the bone structure develops inside this mass in what is called the mesenchyme. The bones that were formed are covered with muscle. Hence, the word "lahm" also applies to them. Another verse which requires extremely delicate interpretation is the following: Sura 39, verse 6: "(God) fashions you inside the bodies of your mothers, formation after formation, in three (veils of) 
darkness." (zulumat) Modern interpreters of the Qur'an sees the above verse as the three anatomical layers that protect the infant during gestation: the abdominal wall, the uterus itself, and the surroundings of the foetus (placenta, embryonic membranes, amniotic fluid). Furthermore, I am obliged to quote this verse for the sake of completeness. The interpretation given here does not seem to be disputable from an anatomical point of view, but is this what the text of the Qur'an really means? It has been known how certain parts appear to be completely out of proportion during embryonic development which is what later develops to become an individual, while others remain in proportion. (Maurice Bucalle, 136).

Another example from verse (75:39) states: "And of him He made two sexes, male and female."

\section{Indexing Verses that is Considered as Scientific Miracles}

Consequently, the classification of Quranic verses that deal with healing and treatment could be listed according to a specific field of medicine. These fields include:

\section{Forensic}

"Yes, [We are] Able [even] to proportion his fingertips." (75:4)

\section{Neonatal}

Nevertheless, we have attributed a man's kindness to his parents. His mother carried him with difficulty, and birthed him with difficulty. Thus, his bearing and weaning takes thirty months until he attained the age of maturity. He reached forty years and said, "Lord, enable me to appreciate the blessings You have bestowed upon me and upon my parents, and to act with righteousness, pleasing You. And improve my children for me. I have sincerely repented to You, and I am of those who have surrendered." (46:15)

\section{Sensory}

Then, when the bearer of good news arrived, he laid it over his face, and he regained his sight. He said, "Did I not say to you that I know from God what you do not know?" (12:96).

\section{Geriatrics}

"O people! If you are in doubt about the Resurrection - We created you from dust, then from a small drop, then from a clinging clot, then from a lump of flesh, partly developed and partly undeveloped. In order to clarify things for you, We settle in the wombs whatever We will for a designated term, and then We bring you out as infants, until you reach your full strength. And some of you will pass away, and some of you will be returned to the vilest age, so 
that he may not know, after having known. And you see the earth still; but when We send down water on it, it vibrates, and swells, and grows all kinds of lovely pairs." (22:5).

\section{Psychiatry}

Say, "I offer you a single advice: devote yourselves to God, in pairs, or individually; and reflect. There is no madness in your friend. He is just a warner to you, before the advent of a severe punishment." (34:46).

\section{Hospice Care}

"Your Lord has commanded that you worship none but Him, and that you be good to your parents. If either of them or both of them reach old age with you, do not say to them a word of disrespect, nor scold them, but say to them kind words. 24 And lower to them the wing of humility, out of mercy, and say, "My Lord, have mercy on them, as they raised me when I was a child."' (17:23-24).

\section{Conclusion}

This paper is an attempt to set a preliminary and simple indexing of Quranic verses that are relevant to healthcare, preventive healthcare, psychological treatment, and medicine. Therefore, the researchers found that: - $\quad$ The major works on this issue was done by Tantawi Jawhari, Maurice Bucalle, and Zaglul al-Najjar.

- Context has a crucial role to play in classifying some verses under the topic of Quran and modern science.

- $\quad$ The data of scientific verses are mostly free of details.

- A dozens of false miracles were found by some modern Muslim theologians who were eager to find similarities between new discoveries and some Quranic verses.

\section{References:}

Arthur J. Arberry (1955). The Koran Interpreted, trans. London: Allen \& Unwin; New York: Macmillan.

Al-I'jaz al-Ilmi wal Ijtima'I fil Quran wal Sunnah (2003). Zaglul Ragib alNejjar.

Al-Islam wal Hadathah (1991). Al-Sharfi Abdul Majeed. Tunis: al-Dar alTunisiyyah lil Nashr. $2^{\text {nd }}$ edition.

Maurice Bucalle. The Bible, the Qur'an and Science. Translated from French to English by Alastair D. Pannell \& the Author.

Monika Richarz. The History of Jews in Europe During the Nineteenth \& Early Twentieth Centuries.

Teun. A. Van Dijk (1977). Text and Context, exploration in the Semantics and Pragmatics of Discourse. London \& New York: Longman linguistic library. 